\title{
Fipronil Insecticide: Novel Application against Triatomine Insect Vectors of Chagas Disease
}

\author{
Antonieta Rojas de Arias/ ${ }^{+}$, Alain Fournet*
}

\begin{abstract}
Departamento de Medicina Tropical, Instituto de Investigaciones en Ciencias de la Salud, Universidad Nacional de Asunción, Casilla de Correo 2511, Asunción, Paraguay *Département Ressources Vivantes, Institut de Recherche pour le Développement, Paris Cedex 10, France.
\end{abstract}

We investigated the efficacy and the residual effect of fipronil $@$ against two species of triatomine bugs, Triatoma infestans and Rhodnius neglectus, in laboratory conditions measuring concentration-response and residual activity on different surfaces (dried mud and lime coated mud). Lethal concentrations $\left(L C_{50,90}\right)$ were determined on filter paper. The higher insecticide efficacy against $\mathrm{R}$. neglectus when compared to $\mathrm{T}$. infestans may be partially attributed to the differences in their biological cycles and genetic structures. Comparison with lambdacyhalothrin wettable powder showed that fipronil mortality rates (above 50\%) were observed on mud blocks and lime-coated mud blocks up to 3 months when fipronil was sprayed at 100 and $200 \mathrm{mg}$ a.i. $/ \mathrm{m}^{2}$. Residual effect deeply decayed after 3 months; and at 6 months post treatment mortality was not observed. In contrast, lambdacyhalothrin showed a long lasting residual effect on both surfaces up to 6 months. Also, it should be mentioned that fipronil had a slow, but lethal activity on the triatomine bugs when wettable formulations were used on porous surfaces.

Key words: fipronil - Triatoma infestans - Rhodnius neglectus - efficacy - residual effect - insecticide/surface interaction

Chagas disease is a major health problem in Latin America. Prevalence varies from 5\% to 60\%; 16-18 million people are infected, with a further 90 million at risk (WHO 1991). Chagas disease is caused by Trypanosoma cruzi, a protozoan parasite that is mainly transmitted by insect vectors (subfamily Triatominae). Lack of a vaccine or suitable drugs means that control of Chagas disease relies on control of the vector achieved through insecticide application. However, reinfestation of sprayed houses can be a major problem caused by lack of sufficient residual effect of insecticides (Schofield \& Dias 1991).

Triatoma infestans Klug, 1834 is an important vector of Chagas disease in Latin America (WHO/TDR 1991). Several insecticides have been tested on this triatomine in order to evaluate the efficacy on triatomines (Schofield 1985). Currently, pyrethroids are commonly used in the spraying campaigns (OPS/WHO 1992). The persistence of insecticide deposits on walls and roofs is an advantage in providing long-term protection against reinfestations (Giga \& Canhao 1992). Thus, success in the residual spraying of houses for the reduction of triatomines depends upon applying an initial application with high impact on triatomines (Schofield 1985) and surface deposits that are lethal to triatomines after a long period of time (Rojas de Arias 1995).

Fipronil is a phenyl pyrazole, which when is used at low doses, is a highly effective insecticide against a broad

This work received financial support from the Rhône-PoulencAgrochemistry Company (now Aventis), Department of Public Health, Lyon, France.

${ }^{+}$Corresponding author. Fax: +595-21-480185. E-mail: sarias@conexion.com.py

Received 5 July 2001

Accepted 19 December 2001 range of insect pests of crops and animals, and is useful in public health applications. As there are no data published regarding the efficacy and the duration of the efficacy of fipronil against triatomine-bugs, we organized the following trials: concentration-response and data on residual activity on different materials (dried mud and lime coated surfaces) under laboratory conditions.

\section{MATERIALS AND METHODS}

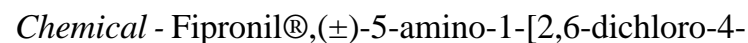
(trifluoromethyl)phenyl]-4-[1R,S)-trifluoromethyl) sulfinyl]-1H-pyrazole-3-carbonitril) was purchased from Rhône-Poulenc Ag. Company, NC, USA (Exp 60720A). The percentage of active ingredients (A. I.) were Aryl heterocycle (Fipronil) 90\% for topical application and contact test, $80 \%$ (wettable powder formulation) for pre-built blocks tests and other ingredients $20 \%$.

Insects - For this test, 5th instars nymphs of T. infestans or R. neglectus (Lent) 1957, were held in laboratory conditions at $25-30^{\circ} \mathrm{C}, 50-70 \%$ relative humidity with $12: 12 \mathrm{~h}$ light/dark periods. The nymphs were synchronized chronologically and physiologically, i. e., only those that moulted to 5 th instar in the same week were fed to repletion a week later. The test was carried out seven days after feeding.

Residual evaluation - Circular disks of filter paper Whatman No. 1 (9 cm diameter) were used and placed in Petri dishes. The papers were impregnated with the solution of formulated insecticide achieving a homogeneous distribution of the insecticide all over the treated area. Each filter paper disk (area $64 \mathrm{~cm}^{2}$ ) was treated with $1 \mathrm{ml}$ of fipronil suspension. After $24 \mathrm{~h}$ when the solvent was evaporated, the insects (10 per group) were held in contact with the treated surface for $24 \mathrm{~h}$. In this particular case, 10 times, 20 times and 40 times LD $_{50}$ values obtained during a previous topical test were used to determine the dose response curve. After the exposure period, 
live insects were maintained in clean vessels fitted with filter paper roosts and closed with nylon netting. For $R$. neglectus and T. infestans the observations were performed at $72 \mathrm{~h}$ after treatment, recording alive, moribund and dead insects. Moribund insects were considered as dead at the time of reading.

Pre-built blocks - Two types of cylindrical blocks of 9 $\mathrm{cm}$ in diameter and $0.5 \mathrm{~cm}$ on thickness, made of mud, and lime painted mud were used as the surface to be treated with fipronil. Blocks were prepared at the Centro de Tecnología Apropiada (CTA), Universidad Católica Nuestra Señora de la Asunción, Asunción, Paraguay. The materials and style of building of these blocks were similar to those used by rural populations in Paraguay. A total of 120 pre-built blocks were used in this study.

Mud blocks - The blocks were made from soil of 60:20:20 sand, lime and clay. Straw or grass was added as a fibre source to reduce the amount of cracks that appeared during the drying process. Compacting and curing were performed in the same way as in the soil-cement blocks.

Lime-coated mud blocks - A mixture of lime and water $(5,000 \mathrm{mg} / 500 \mathrm{ml})$ was prepared and continuously stirred before application by brushing onto dried mud blocks. Two coats were applied on the blocks with 15 min drying period in between. Fifteen to 23 -instar, T. infestans nymphs were exposed to either the $\mathrm{LC}_{90}$ or twice the $\mathrm{LC}_{90}$ dose of fipronil applied to process-built blocks of housing materials at rates of $25,50,100$ and $200 \mathrm{mg} / \mathrm{m}^{2}$. The insects were held in place by bioassay cones (designed for mosquito bioassays on walls) attached to the blocks by nails. The nymphs were held on the treated surfaces for $72,120 \mathrm{~h}$ or 7 days. Mortality rates were recorded and after the exposure period alive insects were transferred onto filter paper and observed in the laboratory for 15 days. An insect was considered dead when no locomotory activity could be seen when the insect was prodded. Moribund insects were considered dead at the time of the reading if they did not show any subsequent recovery of activity during the next 15 days. Untreated surfaces were used as control.

Statistical analysis - The $\mathrm{LC}_{50}$ and $\mathrm{LC}_{90}$ values expressed in $\mathrm{mg} / \mathrm{m}^{2}$ were determined by data analysis program (Toxicologie®, G. Febvay, INSA 406, F-69621 Villeurbanne France) using the probit method of analysis and the correlation coefficient.

\section{RESULTS AND DISCUSSION}

The results obtained in the comparison between fipronil and lambdacyhalothrin up to three months post spraying and the application on two species, T. infestans and $R$. neglectus, indicate that fipronil could provide a good overall control of triatomines on various substrates.

The difference in efficacy on the two species as shown in Table I, may be partially attributed to the differences in the biological cycles, anatomy and their genetic structures or due to differences in their detoxificant capacities (Casabé \& Wood 1998). Assays were performed in two different occasions and strong differences were maintained consistently. Wood et al. (1982) found important differences on insecticide susceptibility among triatomine stages, age in the same stage, starving period and proximity to molt, as well.
Differences observed for $R$. neglectus were remarkable, showing doses that were 3.6 times lower than those used for T. infestans (Table I). It is commonly known that insect populations exhibit a wide range of individual variation in susceptibility to insecticides, a fact that could explain the high variation observed in our application on R. neglectus (Zerba et al. 1989). On the other side, Oliveira Filho (1999) compared several insecticides on different triatomines species and the genera Rhodnius was the most susceptible of the triatomines tested.

In previous studies $T$. infestans was susceptible to lambdacyhalothrin WP10 at lower doses than those of

\section{TABLE I}

Effects of fipronil on 5th instar Triatoma infestans and Rhodnius neglectus by contact test on filter paper

\begin{tabular}{lccc}
\hline Insects & $\begin{array}{c}\mathrm{LC}_{50} \\
\mathrm{mg} \mathrm{m}^{-2}\end{array}$ & $\begin{array}{c}\mathrm{LC}_{90} \\
\mathrm{mg} \mathrm{m}^{-2}\end{array}$ & $\begin{array}{c}\text { Correlation } \\
\text { coefficient }\end{array}$ \\
\hline T. infestans & 106.7 & 190.6 & 0.95 \\
R. neglectus & $(78.6-134.8)$ & $(156.1-225.2)$ & \\
& 29.5 & 52.1 & 0.99 \\
& $(7.0-52.1)$ & $(26.6-78.7)$ & \\
\hline
\end{tabular}

The values in parenthesis are the confidence limits (5\%).

fipronil in this study, showing a $\mathrm{LC}_{50}$ and $\mathrm{LC}_{90}$ of $32.7 \mathrm{mg}$ c.a. $/ \mathrm{m}^{2}$ and $62.5 \mathrm{mg} \mathrm{c.a.} / \mathrm{m}^{2}$, respectively (Rojas de Arias 1995). Tables II and III report the mortality rates by time exposure to mud and lime-coated mud blocks treated with both insecticides. Results obtained show that fipronil had half of the insecticide activity demonstrated by lambdacyhalothrin at $72 \mathrm{~h}$ of time exposure, and at a concentration of 50-62 mg a.c. $/ \mathrm{m}^{2}$ in blocks at 30 days post-treatment. However, fipronil activity is higher on mud blocks at 30 days of post-treatment when compared with results obtained at three months of post-treatment. At this time, residual effect over $50 \%$ of mortality was only observed at 100 and $200 \mathrm{mg}$ a.c $/ \mathrm{m}^{2}$ after 7 days of exposure. At 6 months post-treatment, fipronil did not show any residual effect.

Overall, on lime-coated mud blocks fipronil showed better activity than on mud blocks. Nevertheless, its activity deeply declined at six months post spraying (Table III). On the other hand, lambdacyhalothrin showed a long lasting residual effect up to 6 months in both types of surfaces, and mortality rates on lime-coated mud blocks were between $33 \%$ and $66 \%$.

It should be noticed that mud and lime-coated mud surfaces are extremely variable in $\mathrm{pH}$ and dust distribution; such factors can reduce the residual activity of fipronil but in these particular assays toxicity, differences were not evident (see Tables II and III). In other studies, however, important variations were noticed between mud surfaces and those covered with lime; the duration of residual efficacy was greater on lime surfaces than on mud substrates (Rojas de Arias 1995).

Additional data are needed beyond those provided for these concentrations because formulation and the nature of the surface greatly influence the efficacy of the 
TABLE II

Triatoma infestans mortality rates following time of exposure to mud blocks treated with fipronil and lambdacyhalothrin WP10 tested one, three and six months post-application

\begin{tabular}{|c|c|c|c|c|c|c|c|}
\hline \multirow[t]{2}{*}{ Insecticide } & \multirow[t]{2}{*}{$\begin{array}{l}\text { Post-treatment } \\
\text { days }\end{array}$} & \multirow[t]{2}{*}{$\begin{array}{l}\text { Concentration } \\
\text { mg a.c. } / \mathrm{m}^{2}\end{array}$} & \multicolumn{5}{|c|}{$\begin{array}{l}\text { Dead triatomines/total (percent) } \\
\text { Time of exposure }\end{array}$} \\
\hline & & & $24 \mathrm{~h}$ & $48 \mathrm{~h}$ & $72 \mathrm{~h}$ & $5 \mathrm{~d}$ & $7 \mathrm{~d}$ \\
\hline Fipronil & 30 & $\begin{array}{r}25 \\
50 \\
100 \\
200\end{array}$ & $\begin{array}{c}0 / 20 \\
(0) \\
0 / 20 \\
(0) \\
0 / 20 \\
(0) \\
0 / 20 \\
(0)\end{array}$ & $\begin{array}{c}2 / 20 \\
(10) \\
10 / 20 \\
(50) \\
0 / 20 \\
(0) \\
0 / 20 \\
(0)\end{array}$ & $\begin{array}{c}2 / 20 \\
(10) \\
11 / 20 \\
(55) \\
5 / 20 \\
(25) \\
4 / 20 \\
(20)\end{array}$ & $\begin{array}{c}5 / 20 \\
(25) \\
12 / 20 \\
(60) \\
13 / 20 \\
(65) \\
10 / 20 \\
(50)\end{array}$ & $\begin{array}{c}8 / 20 \\
(40) \\
12 / 20 \\
(60) \\
13 / 20 \\
(65) \\
10 / 20 \\
(50)\end{array}$ \\
\hline Lambdacyhalothrin & 30 & $\begin{array}{c}30 \\
62,5 \\
125\end{array}$ & $\begin{array}{c}1 / 15 \\
(6.7) \\
1 / 15 \\
(6.7) \\
2 / 15 \\
(13.3)\end{array}$ & $\begin{array}{c}8 / 15 \\
(53.3) \\
11 / 15 \\
(73.3) \\
2 / 15 \\
(13.3)\end{array}$ & $\begin{array}{c}15 / 15 \\
(100) \\
12 / 15 \\
(80) \\
13 / 15 \\
(86.7)\end{array}$ & $\begin{array}{c}- \\
12 / 15 \\
(80) \\
13 / 15 \\
(86.7)\end{array}$ & $\begin{array}{c}- \\
15 / 15 \\
(100) \\
15 / 15 \\
(100)\end{array}$ \\
\hline Fipronil & 90 & $\begin{array}{r}25 \\
50 \\
100 \\
200\end{array}$ & $\begin{array}{c}0 / 20 \\
(0) \\
0 / 20 \\
(0) \\
2 / 20 \\
(10) \\
0 / 20 \\
(0)\end{array}$ & $\begin{array}{c}0 / 20 \\
(0) \\
0 / 20 \\
(0) \\
2 / 20 \\
(10) \\
0 / 20 \\
(0)\end{array}$ & $\begin{array}{c}1 / 20 \\
(5) \\
0 / 20 \\
(0) \\
4 / 20 \\
(20) \\
0 / 20 \\
(0)\end{array}$ & $\begin{array}{c}1 / 20 \\
(5) \\
1 / 20 \\
(5) \\
6 / 20 \\
(30) \\
3 / 20 \\
(15)\end{array}$ & $\begin{array}{c}2 / 20 \\
(10) \\
2 / 20 \\
(10) \\
11 / 20 \\
(55) \\
17 / 20 \\
85)\end{array}$ \\
\hline Lambdacyhalothrin & 90 & $\begin{array}{c}30 \\
62,5 \\
125\end{array}$ & $\begin{array}{c}0 / 15 \\
(0) \\
0 / 15 \\
(0) \\
1 / 15 \\
(6.7)\end{array}$ & $\begin{array}{c}0 / 15 \\
(0) \\
0 / 15 \\
(0) \\
1 / 15 \\
(6.7)\end{array}$ & $\begin{array}{c}2 / 15 \\
(13.3) \\
0 / 15 \\
(0) \\
3 / 15 \\
(20)\end{array}$ & $\begin{array}{c}5 / 15 \\
(33.3) \\
0 / 1 \\
(0) \\
3 / 15 \\
(20)\end{array}$ & $\begin{array}{c}7 / 15 \\
(46.7) \\
3 / 15 \\
(20) \\
6 / 15 \\
(40)\end{array}$ \\
\hline Fipronil & 180 & $\begin{array}{r}25 \\
50 \\
100 \\
200\end{array}$ & $\begin{array}{c}0 / 20 \\
(0) \\
0 / 20 \\
(0) \\
0 / 20 \\
(0) \\
0 / 20 \\
(0)\end{array}$ & $\begin{array}{c}0 / 20 \\
(0) \\
0 / 20 \\
(0) \\
0 / 20 \\
(0) \\
0 / 20 \\
(0)\end{array}$ & $\begin{array}{c}0 / 20 \\
(0) \\
0 / 20 \\
(0) \\
0 / 20 \\
(0) \\
0 / 20 \\
(0)\end{array}$ & $\begin{array}{c}0 / 20 \\
(0) \\
0 / 20 \\
(0) \\
0 / 20 \\
(0) \\
0 / 20 \\
(0)\end{array}$ & $\begin{array}{c}0 / 20 \\
(0) \\
0 / 20 \\
(0) \\
0 / 20 \\
(0) \\
0 / 20 \\
(0)\end{array}$ \\
\hline Lambdacyhalothrin & 180 & $\begin{array}{c}30 \\
62,5 \\
125\end{array}$ & $\begin{array}{c}0 / 15 \\
(0) \\
0 / 15 \\
(0) \\
3 / 15 \\
(20)\end{array}$ & $\begin{array}{c}0 / 15 \\
(0) \\
0 / 15 \\
(0) \\
4 / 15 \\
(26.7)\end{array}$ & $\begin{array}{c}0 / 15 \\
(0) \\
0 / 15 \\
(0) \\
6 / 15 \\
(40)\end{array}$ & $\begin{array}{c}0 / 15 \\
(0) \\
0 / 15 \\
(0) \\
9 / 15 \\
(60)\end{array}$ & $\begin{array}{c}2 / 15 \\
(13.3) \\
2 / 15 \\
(13.3) \\
9 / 15 \\
(60)\end{array}$ \\
\hline
\end{tabular}

insecticides. The finding that fipronil was highly toxic to triatomines on residual surface application, but had lower toxicity in our block tests shows that the method of exposure is critical in evaluating insecticides (Arthur 1979, White 1982, Williams et al. 1982, Giga \& Canhao 1992).

A knockdown resistance was also observed in triatomines exposed to contact exposure of fipronil and toxicity developed only after 7 days of application. Knockdown resistance is usually associated to reduced sensitivity of the central nervous system (CNS) and involves modification of the sodium-channel pharmacology in some cases (Bloomquist 1996, Bloomquist et al. 1997). Fipronil interferes with the passage of chloride ions through the Gamma-Amino Butyric Acid (GABA) regulated chloride channel, thereby disrupting CNS activity and, at sufficient doses, causing death (Cole et al. 1993, Bloomquist 1996). Recently, Hainzl et al. (1998) have described that the mechanisms for selectivity toxicity of fipronil insecticide were due to differences in the GABA receptor sensitivity from the non-competitive blocking site and are also dependent on the relative rates of conversion to the metabolite photoproducts. 
TABLE III

Triatoma infestans mortality rates following time of exposure to lime-coated mud blocks treated with fipronil and lambdacyhalothrin WP10 tested one, three and six months post-application

\begin{tabular}{|c|c|c|c|c|c|c|c|}
\hline \multirow[t]{2}{*}{ Insecticide } & \multirow[t]{2}{*}{$\begin{array}{l}\text { Post-treatment } \\
\text { days }\end{array}$} & \multirow[t]{2}{*}{$\begin{array}{l}\text { Concentration } \\
\text { mg a.c. } / \mathrm{m}^{2}\end{array}$} & \multicolumn{5}{|c|}{$\begin{array}{l}\text { Dead triatomines/total (percent) } \\
\text { Time of exposure }\end{array}$} \\
\hline & & & $24 \mathrm{~h}$ & $48 \mathrm{~h}$ & $72 \mathrm{~h}$ & $5 \mathrm{~d}$ & $7 \mathrm{~d}$ \\
\hline Fipronil & 30 & $\begin{array}{r}25 \\
50 \\
100 \\
200\end{array}$ & $\begin{array}{c}0 / 20 \\
(0) \\
0 / 20 \\
(0) \\
0 / 20 \\
(0) \\
0 / 20 \\
(0)\end{array}$ & $\begin{array}{c}0 / 20 \\
(0) \\
0 / 20 \\
(0) \\
2 / 20 \\
(10) \\
4 / 20 \\
(20)\end{array}$ & $\begin{array}{c}0 / 20 \\
(0) \\
1 / 20 \\
(5) \\
7 / 20 \\
(35) \\
9 / 20 \\
(45)\end{array}$ & $\begin{array}{c}1 / 20 \\
(5) \\
8 / 20 \\
(40) \\
10 / 20 \\
(50) \\
11 / 20 \\
(55)\end{array}$ & $\begin{array}{c}1 / 20 \\
(5) \\
10 / 20 \\
(100) \\
10 / 20 \\
(50) \\
50 / 20 \\
(100)\end{array}$ \\
\hline Lambdacyhalothrin & 30 & $\begin{array}{c}30 \\
62,5 \\
125\end{array}$ & $\begin{array}{c}0 / 15 \\
(0) \\
10 / 15 \\
(66.7) \\
11 / 15 \\
(73.3)\end{array}$ & $\begin{array}{c}8 / 15 \\
(53.3) \\
10 / 15 \\
(66.7) \\
12 / 15 \\
(80)\end{array}$ & $\begin{array}{c}12 / 15 \\
(80) \\
10 / 15 \\
(66.7) \\
13 / 15 \\
(86.7)\end{array}$ & $\begin{array}{c}13 / 15 \\
(86.7) \\
10 / 15 \\
(66.7) \\
13 / 15 \\
(86.7)\end{array}$ & $\begin{array}{l}15 / 15 \\
(100) \\
15 / 15 \\
(100) \\
15 / 15 \\
(100)\end{array}$ \\
\hline Fipronil & 90 & $\begin{array}{r}25 \\
50 \\
100 \\
200\end{array}$ & $\begin{array}{c}1 / 20 \\
(5) \\
1 / 20 \\
(5) \\
1 / 20 \\
(5) \\
2 / 20 \\
(10)\end{array}$ & $\begin{array}{c}1 / 20 \\
(5) \\
2 / 20 \\
(10) \\
4 / 20 \\
(20) \\
9 / 20 \\
(45)\end{array}$ & $\begin{array}{c}5 / 20 \\
(25) \\
2 / 20 \\
(10) \\
7 / 20 \\
(35) \\
12 / 20 \\
(60)\end{array}$ & $\begin{array}{c}6 / 20 \\
(30) \\
4 / 20 \\
(20) \\
7 / 20 \\
(35) \\
20 / 20 \\
(100)\end{array}$ & $\begin{array}{c}12 / 20 \\
(60) \\
6 / 20 \\
(30) \\
7 / 20 \\
(35) \\
-\end{array}$ \\
\hline Lambdacyhalothrin & 90 & $\begin{array}{l}30 \\
62,5 \\
125\end{array}$ & $\begin{array}{c}1 / 15 \\
(6.7) \\
0 / 15 \\
(0) \\
1 / 15 \\
(6.7)\end{array}$ & $\begin{array}{c}1 / 15 \\
(6.7) \\
0 / 15 \\
(0) \\
4 / 15 \\
(26.7)\end{array}$ & $\begin{array}{c}1 / 15 \\
(6.7) \\
0 / 15 \\
(0) \\
4 / 15 \\
(26.7)\end{array}$ & $\begin{array}{c}3 / 15 \\
(20) \\
0 / 15 \\
(0) \\
4 / 15 \\
(26.7)\end{array}$ & $\begin{array}{c}3 / 15 \\
(20) \\
2 / 15 \\
(13.3) \\
4 / 15 \\
(26.7)\end{array}$ \\
\hline Fipronil & 180 & $\begin{array}{r}25 \\
50 \\
100 \\
200\end{array}$ & $\begin{array}{c}0 / 20 \\
(0) \\
0 / 20 \\
(0) \\
0 / 20 \\
(0) \\
0 / 20 \\
(0)\end{array}$ & $\begin{array}{c}0 / 20 \\
(0) \\
0 / 20 \\
(0) \\
0 / 20 \\
(0) \\
0 / 20 \\
(0)\end{array}$ & $\begin{array}{c}0 / 20 \\
(0) \\
0 / 20 \\
(0) \\
0 / 20 \\
(0) \\
0 / 20 \\
(0)\end{array}$ & $\begin{array}{c}0 / 20 \\
(0) \\
0 / 20 \\
(0) \\
0 / 20 \\
(0) \\
0 / 20 \\
(0)\end{array}$ & $\begin{array}{c}0 / 20 \\
(0) \\
0 / 20 \\
(0) \\
0 / 20 \\
(0) \\
0 / 20 \\
(0)\end{array}$ \\
\hline Lambdacyhalothrin & 180 & $\begin{array}{c}30 \\
62,5 \\
125\end{array}$ & $\begin{array}{c}0 / 15 \\
(0) \\
5 / 15 \\
(33.3) \\
6 / 15 \\
(40)\end{array}$ & $\begin{array}{c}3 / 15 \\
(20) \\
5 / 15 \\
(33.3) \\
7 / 15 \\
(46.7)\end{array}$ & $\begin{array}{c}5 / 15 \\
(33.3) \\
5 / 15 \\
(333) \\
7 / 15 \\
(46.7)\end{array}$ & $\begin{array}{c}10 / 15 \\
(66.7) \\
5 / 15 \\
(33.3) \\
7 / 15 \\
(46.7)\end{array}$ & $\begin{array}{c}10 / 15 \\
(66.7) \\
5 / 15 \\
(33.3) \\
7 / 15 \\
(46.7)\end{array}$ \\
\hline
\end{tabular}

In our assays, fipronil had a slow but lethal activity on triatomine bugs, as can be seen in Tables II and III, as the total mortality increased after $24 \mathrm{~h}$, up to 7 days.

In conclusion, fipronil appears to give moderate residual efficacy on mud and lime-coated mud blocks taking into account its residual effect up to three months at $200 \mathrm{mg}$ a.c $/ \mathrm{m}^{2}$ with mortality rates around $50 \%$. Due to its lower $\mathrm{LC}_{50}$ and $\mathrm{LC}_{90}$ on $R$. neglectus, fipronil potential for practical use in triatomine control should be considered.

\section{ACKNOWLEDGMENTS}

To the Rhône-Poulenc-Agrochemistry Company (now Aventis), Department of Public Health, Lyon, France for providing fipronil. To Dr Eric Planchon and Dr Marten van Maanen (Rhône-Poulenc-Agrochemistry) and Dr Pierre Guillet (IRD, Montpellier) for their help and assistance in the preparation of the experiments.

\section{REFERENCES}

Arthur FH 1979. Residual efficacy of cyfluthrin emulsifiable concentrate and wettable powder formulations on porous 
concrete and on concrete sealed with commercial products prior to insecticide application. J Stored Prod Res 30: 7986.

Bloomquist JR 1996. Ion channels as target for insecticides. Annu Rev Entomol 41: 163-190.

Bloomquist JR, Ferguson HJ, Cox ED, Reddy MS, Cook JM 1997. Mode of action of beta-carboline convulsants on the insect nervous system and their potential as insecticides. Pestic Sci 51: 1-6.

Casabé NE, Wood EJ 1998. Causas bioquímicas de la susceptibilidad diferencial a piretroides entre Rhodnius proxilus (Stal.) y Triatoma infestans (Klug) (Heteroptera): Reduviidae). Libro de resumenes, IV Congreso Argentino de Entomología, Mar del Plata, Argentina, p. 264.

Cole LM, Nicholson RA, Casida JE 1993. Action of phenyl pyrazoles insecticides at the GABA-gated chloride channels. Pestic Biochem Physiol 46: 47-54.

Giga DP, Canhao SJ 1992. Persistence of insecticide spray deposits on different surfaces against Prostephanus truncatus (Horn) and Sitophilus zeamais (Mostch.). Ins Sci Appl 13: 755-762.

Hainzl D, Cole LM, Casida JE 1998. Mechanisms for selective toxicity of fipronil insecticide and its sulfone metabolite and desulfinyl photoproduct. Chem Res Toxicol 11: 15291535.

Oliveira Filho AM 1999. Differences of susceptibility of five triatomine species to pyrethroid insecticides. Implication for Chagas disease vector control. Mem Inst Oswaldo Cruz 94: 425-428.

OPS/WHO 1992. Iniciativa del Cono Sur. Estado actual de las acciones para la eliminación de la transmisión vectorial e interrupción de la transmisión transfusional al T. cruzi, PNSP/ 92-18 Rev.1.

Rojas de Arias A 1995. Chagas Disease Control Techniques in Paraguay, Thesis, School of Biological Sciences, University of Bangor, $262 \mathrm{pp}$.

Schofield C 1985. Control of Chagas disease vectors. Br Med Bull 41: 187-194.

Schofield CJ, Dias JCP 1991. A cost benefit analysis of Chagas disease control. Mem Inst Oswaldo Cruz 86: 285-295.

White NDG 1982. Effectiveness of malathion and perimiphosmethyl applied to plywood and concrete to control Prostephanus truncatus (Coleoptera: Bostrichidae). Proc Entomol Soc Ont 113: 65-69.

Williams P, Semple RL, Amos TG 1982. Relative toxicity and persistence of one carbamate and three organophosphate insecticide on concrete, wood and iron surfaces for control of grain insects. Gen Appl Entomol 14: 35-40.

WHO 1991. Control of Chagas Disease. Report of an Expert Committee, Technical Report. Series 811, Geneva.

WHO/TDR 1991. Control of Chagas Disease, Technical Report Series 811, Geneva, 95 pp.

Wood EJ, Picollo de Villar MI, Melgen P, Zerba EN 1982. Mode of action of organophosphorus insecticides on T. infestans. An Asoc Quim Argen 70: 801.

Zerba NE, Licastro SA, Wood EJ, Picollo de Villar, MI 1989. Insecticides: mechanism of action. In RR Brenner \& A de la Merced Stoka (eds), Chagas Disease Vectors, Vol III, Biochemical Aspect and Control, CRC Press, Florida, USA, p. 101-120. 